\title{
Comparative Study between Unilateral Inguinal Hernia by Open Technique versus TAPP Repair
}

\author{
AHMED A. BASIOUNY, M.Sc.; RAGHEB A. RAGHEB, M.D. and ASHRAF E. ELSHARKAWY, M.D. \\ The Department of General Surgery, Faculty of Medicine, Al-Azhar University (Girls)
}

\begin{abstract}
Background: Inguinal hernia repair is one of the most widely performed surgical procedure. Amongst the techniques used, the Open Lichtenstein Repair (OLR) is still the most widely performed. However, in the last decade there has been an increased interest in the laparoscopic approach for inguinal hernia repair, mainly represented as the Trans-Abdominal Pre-Peritoneal (TAPP) technique. As described in recent studies, TAPP approach entails the benefits of minimally invasive surgery, such as less pain and earlyrecovery.
\end{abstract}

Aim of Study: This study aims to compare between lichtenstein repair of inguinal hernia and transabdominal preperitoneal repair of inguinal hernia (TAPP) as regard their hospital stay, post-operative complications and short-term recurrence.

Patients and Methods: Our study was carried out on (40) male patients with inguinal hernia attendees Kobry El-Qobba Military and Alzahraa Hospital; Al-Azhar University between April 2019-Octoper 2019, 20 patients underwent laparoscopic Trans-Abdominal Pre-Peritoneal (TAPP) repair and 20 patients underwent open Lichtenstein repair.

Results: In our study the mean operative time was ( 97.50 $\pm 19.97)$ minute for TAPP, $(70.30 \pm 19.55)$ minute for open Lichtenstein repair. None of our patients had intra-operative complications such as (vascular injury... etc). There was one patient with wound infection (5\%) for TAPP repair versus two patients seroma $(10 \%)$, one patient hematoma $(5 \%)$ and one patient wound infection (5\%) but the difference between both groups was statistically insignificant. There was no significant difference in terms of hernia recurrence. This study confirmed less post-operative pain day 0 , day 1 and day 7 post-operatively.

There was no significant difference in 1 and 6 month post-operatively.

Conclusion: Our study showed that laparoscopic TAPP approach for inguinal hernia repair is safe and reduces early post-operative pain. Furthermore, it is related to less complications. Significantly although it takes a longer operative time.

Correspondence to: Dr. Ahmed A. Basiouny, The Department of General Surgery, Faculty of Medicine, Al-Azhar University (Girls)
Key Words: Unilateral Inguinal Hernia - Open Technique versus TAPP repair.

\section{Introduction}

HERNIA is defined as an abnormal protrusion of an organ or tissue through a defect in its surrounding walls [1].

Hernias of the anterior abdominal wall include: Inguinal and ventral hernias [2]

Inguinal hernia repair is the most frequently performed operation in general surgery. The most frequently used tension-free open techniques include Lichtenstein, Shouldice, and Bassini repair, The Lichtenstein repair involves the implantation of a mesh prosthesis ventral to the transversalis fascia. On the other hand, both Shouldice and Bassini repairs are nonmesh techniques that use a continuous non-absorbable suture to reconstruct the muscle layers in order to strengthen the inguinal floor. A common minimally invasive approach is the Transabdominal Pre-Peritoneal (TAPP) technique, which places a mesh prosthesis into the pre-peritoneal space dorsal to the transversalis fascia [3].

Surgical repair of inguinal hernia is a common procedure in adult men. However, post-operative pain and disability are frequent after the introduction of tension-free surgical repair with the use of prosthetic mesh, patient's comfort was reported to be substantially improved over that obtained by the traditional, tension-producing techniques [4].

A laparoscopic method of performing a tensionfree repair has subsequently been reported to result in less pain in the immediate post-operative period and earlier return to normal activities than the open repair technique. The ideal method of hernia repair would cause minimal discomfort to the patient, 
both during the surgical procedure and in the postoperative course. It would be technically simple to perform and easy to learn, would have a low rate of complications and recurrence and would require only a short period of convalescence [4].

The optimal operative approach for inguinal hernia repair is still debatable. Most techniques involve reinforcement of the inguinal floor with a synthetic or biologic material to obtain a tensionfree repair. Open mesh-based repairs are considered easier to learn and to teach than laparoscopic repairs. But laparoscopic mesh repair has a definite role in modern surgery. Laparoscopic mesh repair of inguinal hernia is associated with greater patient satisfaction and better cosmetic results than its open counterpart but has a longer learning curve. Transabdominal Pre-Peritoneal mesh repair (TAPP) the technique performed laparoscopically for inguinal hernia. Therefore, the safety, benefits and periods of convalescence of laparoscopic mesh repair over open mesh repair should be evaluated [4].

Open hernia repair can be done under general, spinal anathesia or local anathesia, but laparoscopic repair requires general anathesia [5].

Therefore, surgeons repairing abdominal wall defects should be familiar with both open and laparoscopic approaches to hernias to offer the patient the most appropriate repair [6] .

Stated that the most common complications of inguinal hernia repair include bleeding, seroma, wound infection, urinary retention, ileus, and injury to adjacent structures. Complications specific to herniorrhaphy and hernioplasty include hernia recurrence, chronic inguinal and pubic pain, and injury to the spermatic cord or testis [7].

Aim of the work:

This study aims to compare between lichtenstein repair of inguinal hernia and transabdominal preperitoneal repair of inguinal hernia (TAPP) as regard their hospital stay, post-operative complications and short term recurrence.

\section{Patients and Methods}

This prospective randomized study included 40 male patients divided into 2 groups:

- Group A: 20 patients underwent laparoscopic Trans-Abdominal Pre-Peritoneal repair (TAPP).

- Group B: 20 patients underwent open Lichtenstein repair.
Patients involved in this study included those attended to the General Surgery Department of Kobri El-Kobba Armed Force Hospitals and AlZahraa Hospital Al-Azhar University aiming the period of April 2019-Octoper 2019.

\section{Inclusion criteria:}

Patients suffered from primary inguinal hernia (Bubonocele type) with an age above 18 years and overall good health.

\section{Exclusion criteria:}

1- Patients less than 18 years old.

2- Recurrent, incarcerated and scrotalhernias.

3- High general anaethesia risk (Cardiac-COPD).

4- Previous lower abdominal surgery.

5- Bilatral inguinalhernia.

6- Female.

All patients included in the study were subjected to:

- History taking, general examination and routine pre-operative investigations as-full laboratory workup including: CBC, PT, PTT, INR, liver function test, kidney function test: ECG, CXR, Ultrasound.

- Informed writtenconsent.

- Evaluations of the operative time, blood loss, mesh size and material, method and material of mesh fixation and any intra-operative complications.

- Post-operative evaluation of pain score (NRS), need for analgesia, length of hospital stay and post-operative complications.

- Follow-up for 6 months to compare the effectiveness and patient satisfaction of these 2 groups.

\section{Anesthesia:}

- General anathesia for laparoscopiccases.

- General or Spinal anathesia for opencases.

Preparation of patient:

- Positioning the patient on the operativetable.

- Placement the patient in supine position.

- Positioning the table as to tilt head 15 degree down in case of TAPP repair.

- Thoroughly painting the operative area of skin.

- Drape patient such as to expose 2/3 of lowerabdomen. 


\section{Operative technique:}

In TAPP:

Dissection started with incising the peritoneum from just anterior and medial to the anterior superior iliac spine to the medial umbilical fold in order to identify Cooper's ligament. Stoppa's parietalization technique will be used for dissection of the spermatic cord from the peritoneum by separating the elements of the spermatic cord from the peritoneum and peritoneal sac. The anatomical landmarks of the pubic bone and inferior eipgastricvessels will be identified. Both blunt and sharp dissection will be used for separating the sac off the anterior abdominal wall. Once the sac is separated the next step is separation of sac from cord structures and dissection for creation of proper lateral space for placement of mesh. Lateral limit of dissection is the anterior superior iliac spine while inferior limit laterally is the psoas muscle. Dissection will be avoided in the "triangle of doom".

At the end of surgery the abdomen will be examined for any possible bowel injury or hemorrhage. All instruments will be removed followed by removal of all ports with Telescope after releasing all the gas. Skin incisions is then closed.

\section{In open lichtenstein technique:}

The inguinal canal is dissected to expose the shelving edge of the inguinal ligament, the pubic tubercle, and sufficient area for mesh. The mesh is a $7 \times 15 \mathrm{~cm}$ rectangle with a rounded medial edge, and it must be large enough to extend 2 to $3 \mathrm{~cm}$ superior to Hesselbach's triangle. The lateral portion of the mesh is split such that the superior tail comprises two thirds of its width, and the inferior tail comprises the remaining one third. The medial edge of the mesh is affixed to the anterior rectus sheath such that it overlaps the pubic tubercle by 1.5 to $2 \mathrm{~cm}$. For fixation of the inferior margin of the mesh, a permanent, synthetic, monofilament suture is used, taking care to avoid placing sutures directly into the periosteum of the pubic tubercle. Fixation is continued along the shelving edge of the inguinal ligament from medial to lateral, ending at the internal ring. The upper tail of the mesh is then fixed to the internal oblique aponeurosis and the medial edge to the rectus sheath using a synthetic, absorbablesuture.

\section{Statistical analysis:}

Patients' data were tabulated and processed using SPSS (17.0) statistical package for Windows 7: Quantitative variables were expressed by means and standard deviation and were analyzed using independent $t$-test, one-way ANOVA test was used to compare more than two groups as regard a quantitative variable (SD $<50 \%$ mean), qualitative data was expressed by frequency and percent and were analyzed using Chi-square: $p$-value $>0.05$ : Insignificant, $p$-value $<0.05$ : Significant, $p$-value $<0.01$ : Highly significant.

\section{Results}

Table (1): Age in both groups.

\begin{tabular}{lll}
\multicolumn{1}{c}{ Age } & \multicolumn{1}{c}{ TAPP } & \multicolumn{1}{c}{ Open } \\
& \multicolumn{1}{c}{ No. $=20$} & \multicolumn{1}{c}{ No.=20 } \\
\hline Mean \pm SD & $35.10 \pm 13.32$ & $42.40 \pm 12.66$ \\
Range & $21-65$ & $24-66$ \\
\hline
\end{tabular}

This table shows the descriptive data of the 40 males patient, twenty patients underwent TAPP repair, their age ranged between 21 and 65 years and mean age (55.42 \pm 14.86$)$ year. The other 20 patients underwent open repair and their age ranged between 24 and 66 and mean age (42.40 \pm 12.66$)$ year.

Table (2): Study of operative time, complications in 20 patients of TAPP repair.

\begin{tabular}{|c|c|}
\hline & $\begin{array}{c}\text { TAPP } \\
\text { No. }=20\end{array}$ \\
\hline $\begin{array}{l}\text { Time of operation (per minute): } \\
\text { Mean } \pm \mathrm{SD} \\
\text { Range }\end{array}$ & $\begin{array}{l}97.50 \pm 19.97 \\
60-130\end{array}$ \\
\hline $\begin{array}{l}\text { Intra-operative complications: } \\
\text { Negative } \\
\text { Positive }\end{array}$ & $\begin{array}{ll}20 & (100.0 \%) \\
0 & (0.0 \%)\end{array}$ \\
\hline $\begin{array}{l}\text { Post-operative complications: } \\
\text { Negative } \\
\text { Seroma } \\
\text { Infection } \\
\text { Hematoma }\end{array}$ & $\begin{array}{ll}19 & (95.0 \%) \\
0 & (0.0 \%) \\
1 & (5.0 \%) \\
0 & (0.0 \%)\end{array}$ \\
\hline $\begin{array}{l}\text { Recurrence: } \\
\text { Negative } \\
\text { Positive }\end{array}$ & $\begin{array}{ll}20 & (100.0 \%) \\
0 & (0.0 \%)\end{array}$ \\
\hline
\end{tabular}

In 20 patient whom underwent TAPP repair the time of operation ranged from 60-130 minute and mean $(97.50 \pm 19.97)$ minute with no intra-operative complication. In 20 patient whom underwent open repair the time of operation ranged from 45-110 minute and mean $(70.30 \pm 19.55)$ minute with no intra-operative complication.

Table (3): Time of operation.

\begin{tabular}{llllll}
\hline $\begin{array}{l}\text { Time of operation } \\
\text { (per minute) }\end{array}$ & \multicolumn{1}{c}{$\begin{array}{c}\text { TAPP } \\
\text { No.=20 }\end{array}$} & $\begin{array}{c}\text { Open } \\
\text { No.=20 }\end{array}$ & $\begin{array}{c}\text { Test } \\
\text { value }\end{array}$ & $\begin{array}{c}p^{-} \\
\text {value }\end{array}$ & Sig. \\
\hline Mean \pm SD & $97.50 \pm 19.97$ & $70.30 \pm 19.55$ & $4.353 \bullet$ & 0.000 & HS \\
Range & $60-130$ & $45-110$ & & & \\
\hline
\end{tabular}

$p$-value $>0.05$ : Non Significant (NS).

$p$-value $<0.05$ : Significant $(\mathrm{S})$

$p$-value <0.01: Highly Significant (HS).

$\bullet:$ Independent $t$-test. 
This table shows that operative time was significantly higher in TAPP repair of inguinal hernia than in open repair with Mean operative time (97.50 $\pm 19.97)$ minute for TAPP against $(70.30 \pm 19.55)$ minute for openrepair.

Table (4): Post-operative pain.

\begin{tabular}{|c|c|c|c|c|c|}
\hline $\begin{array}{l}\text { Post-operative } \\
\text { pain }\end{array}$ & $\begin{array}{c}\text { TAPP } \\
\text { No. }=20\end{array}$ & $\begin{array}{c}\text { Open } \\
\text { No. }=20\end{array}$ & $\begin{array}{c}\text { Test } \\
\text { value• }\end{array}$ & $\begin{array}{c}p- \\
\text { value }\end{array}$ & Sig. \\
\hline \multicolumn{6}{|l|}{ DAY 0: } \\
\hline Mean \pm SD & $1.85 \pm 1.04$ & $3.50 \pm 1.00$ & -5.114 & 0.000 & HS \\
\hline Range & $0-4$ & $1-5$ & & & \\
\hline \multicolumn{6}{|l|}{$D A Y$ 1: } \\
\hline Mean \pm SD & $1.20 \pm 0.62$ & $2.45 \pm 0.76$ & -5.720 & 0.000 & HS \\
\hline Range & $0-2$ & $1-4$ & & & \\
\hline \multicolumn{6}{|l|}{1 week: } \\
\hline Mean \pm SD & $0.15 \pm 0.37$ & $0.80 \pm 0.62$ & -4.058 & 0.000 & HS \\
\hline Range & $0-1$ & $0-2$ & & & \\
\hline \multicolumn{6}{|l|}{1 month: } \\
\hline Mean $\pm S D$ & $0.00 \pm 0.00$ & $0.15 \pm 0.37$ & -1.831 & 0.075 & NS \\
\hline Range & $0-0$ & $0-1$ & & & \\
\hline \multicolumn{6}{|l|}{6 month: } \\
\hline Mean \pm SD & $0.00 \pm 0.00$ & $0.00 \pm 0.00$ & NA & NA & NA \\
\hline Range & $0-0$ & $0-0$ & & & \\
\hline
\end{tabular}

This table shows significantly less pain in TAPP repair when compared to open repair from day 0 to 1 week post-operative. While later on there was no significant difference.

\section{Discussion}

Inguinal hernia repair is one of the most widely performed surgical procedure. Amongst the techniques used, the open Lichtenstein repair is still the most widely performed. However, in the last decade there has been an increased interest in the laparoscopic approach for inguinal hernia repair, mainly represented as the Trans-Abdominal PrePeritoneal (TAPP) technique [8] .

TAPP approach entails the benefits of minimally invasive surgery, such as less pain and early recovery. We expect that these benefits would be more apparent in the treatment of inguinal hernias [9] .

One study sound that overall mean age was $49 \pm 14.9$ years (range $=18-82$-years). The mean age of patients in group I was $47.8 \pm 16.0$ years (range $=$ $18-82$ years) and that of group II was $51.3 \pm 13.8$ years (range $=27-78$ years). There was no statistically significant difference between the two groups in terms of age distribution $(p=0.414)$ [10]
In another randomized study the median age of the laparoscopic group at the time of operation was 61.5 years (range 20-80 years; IQR 51.7-67.5) compared with the open group of 61 years (range 25-88 years; IQR 52-74). There was a significantly higher mortality rate in the open group compared with the laparoscopic group (8/60 vs. 20/60, $p=$ 0.0166) [11]

In our study a descriptive data of the 40 males patient, twenty patients underwent TAPP repair, their age ranged between 21 and 65 years and mean age $(55.42 \pm 14.86)$ year. The other 20 patients underwent open repair and their age ranged between 24 and 66 and mean age $(42.40 \pm 12.66)$ year with no efficacy on mortality or morbidity which is same as two studies of the three previousstudies.

Regarding the duration of the operation, in the random-effects model, all trials showed that the mean or medium time of operation in the TAPP group was longer than that in the Lichtenstein group. The operation time was shorter in the Lichtenstein group with a mean difference of $6.8 \mathrm{~min}$ (95\% CI, -0.68-14.25) [12].

In other study the average operation time was 59.669 .9 minutes for the Lichtenstein group and 64.4 68.4 minutes for the TAPP group. TAPP operation time showed a trend toward increasing in comparison with Lichtenstein time, but this difference did not reach statistical significance ( $p 5$ 0.068) [13].

In our study the mean operative time was ( 97.50 $\pm 19.97)$ minute for TAPP, $(70.30 \pm 19.55)$ minute for open Lichtenstein repair, which is compatible to the the previous studies.

Main studies for primary unilateral inguinal hernia, found that TAPP is associated with increased risk of intra-operative complications relative to open inguinal hernia repair [14] .

Other studies cited that the overall complication rate of the laparoscopic group was lower than that of the open group (13.98 vs. $18.11 \% ; p=0.027)$. The two groups had similar intraoperative and short-term post-operative complication rates [15]

In our study none of our patients had intraoperative complications which is appropriate with one of two previous studies.

In previous study according to early complications in Lichtenstein group, early complications (superficial infection, hematoma, seroma, and urinary retention) were observed (14.3\%), whereas in the TAPP group, the number of complications 
was higher $(8 ; 33.3 \%)$. This difference did not reach statistical significance ( $p 50.19)$ [13].

A recent study terms that post-operative complications, a total of 58 patients was analyzed $(98.30 \%)$. Nineteen minor post-operative complications were detected (32.8\%), 10 of them belonging to the open hernioplasty group, representing $27.8 \%$ of complications within that group, and 9 of them belonging to the laparoscopic group, representing $40.9 \%$ [16].

In our study there was one patient with wound infection (5\%) for TAPP repair versus two patients seroma (10\%), one patient hematoma (5\%) and one patient wound infection (5\%) but the difference between both groups was statistically insignificant.

A study reported that six trials reported details of hernia recurrence. In the random-effects analysis of 337 patients who underwent TAPP and 322 patients who underwent Lichtenstein repair, there was no significant difference $(\mathrm{OR}=1.17 ; 95 \% \mathrm{CI}$, 0.39-3.57) [12].

Other studies found that recurrence is significantly more common after laproscopic inguinal hernia repair than after open inguinal hernia repair for primary, unilateral inguinal hernia but rates of recurrence after repair of recurrent hernias are similar in the groups. Indeed, a recent meta-analysis comparing exclusively laproscopic inguinal hernia repair with open inguinal hernia repair for recurrent inguinal hernia found no difference in recurrence. The present data suggest that the increased recurrence rate after laproscopic inguinal hernia repair is due to the use of the TEP technique as there was no significant difference in hernia recurrence when TAPP was compared with open inguinal herniarepair [17].

In our study there was no significant difference in terms of hernia recurrence. May be due to the short period of follow-up and the small number of patients.

A new study confirmed that the minimally invasive approach is associated with less early post-operative pain compared with the open Lichtenstein repair. In the late post-operative time, VAS is similar in both groups [18]

Other study clarified that post-operative pain and complications are closely related. One of the reasons for less post-operative pain in the TAPP procedure lies mainly in the lower rate of complications that occurred in this approach [19].
Our study confirmed less post-operative pain day 0 , day 1 and day 7 post-operatively.

There was no significant difference in 1 and 6 month post-operatively.

\section{Conclusion:}

Our study showed that laparoscopic TAPP approach for inguinal hernia repair is safe and reduces early post-operative pain. Furthermore, it is related to less complications. Significantly although it takes a longer operative time the major drawback with laparoscopic TAPP is the leering curve of it otherwise in experienced hand TAPP is as good as open surgery with better cosmesis.

\section{References}

1- COURTNEY M.T., DANIEL B.B. and KENNETH L.M.: Sabiston Text book of Surgery, Nineteenth Edition hernia in Chapter 46, 2012, 1114-40, 2012.

2- PODOLSKY E.R., MOULAS A., WU A.S., et al.: Single port access (SPA) laparoscopic ventral hernia repair: Initial report of 30 cases, Surg. Endosc., 24 (7): 1557-61, 2010.

3- JAMES W.J., WAY J.A., ESLICK G.D. and COX M.R.: Transabdominal pre-peritoneal versus open repair for primary unilateral inguinal hernia: A meta-analysis. World journal of surgery, 42 (5): 1304-11, 2018.

4- FAISAL M.F., ISLAM K.S., KHAN M.M., BISWAS A.K., AZAD M.A. and REZA M.N.: Early Clinical Outcomes Following Laparoscopic Vs. Open Mesh Repair of Inguinal Hernia 85. KYAMC Journal, 10 (2): 85-9, 2019.

5- McCORMACK K., GRANT A. and SCOTT N.: EU Hernia Trialists Collaboration value of updating asystematic review in surgery using individual patient data. $\mathrm{Br}$. J. Surg., 91 (4): 495-9, 2014.

6- JOHN L.C. and ANDREW M.C.: Laparoscopic ventral hernia repair in Current Surgical Therapy, Eleventh Edition, 2014 Pages, 1337-42, 2014.

7- BRUNICARDI F.C., WAGNER J.P., AMID P.K. and CHEN D.C.: Schwartz's principles of surgery. McGrawhill. 10 ed. Chap. 37: pp. 1496-518, 2015.

8- ANTONIOU S.A., ANTONIOU G.A., BARTSCH D.K., et al.: Transabdominal preperitoneal versus totally extraperitoneal repair of inguinal hernia: A meta-analysis of Randomized studies. Am. J. Surg., 206 (245e252): e1, 2013.

9- CLAUS C.M., ROCHA G.M., CAMPOS A.C., et al.: Prospective, randomized and controlled Study of mesh displacement after laparoscopic inguinal repair: Fixation versus No fixation of mesh. Surg. Endosc., 30 (3): 113440, 2016.

10- KRISHNA A., MISRA M.C., BANSAL V.K., KUMAR S., RAJESHWARI S. and CHABRA A.: Laparoscopic inguinal hernia repair: Transabdominal preperitoneal (TAPP) versus totally extraperitoneal (TEP) approach: A 
prospective randomized controlled trial. Surgical endoscopy, 26 (3): 639-49, 2012.

11- BIGNELL M., PARTRIDGE G., MAHON D. and RHODES M.: Prospective randomized trial of laparoscopic (transabdominal preperitoneal-TAPP) versus open (mesh) repair for bilateral and recurrent inguinal hernia: Incidence of chronic groin pain and impact on quality of life: Results of 10 year follow-up. Hernia, 16 (6): 635-40, 2012.

12- SCHEUERMANN U., NIEBISCH S., LYROS O., JANSEN-WINKELN B. and GOCKEL I.: Transabdominal Preperitoneal (TAPP) versus Lichtenstein operation for primary inguinal hernia repair-A systematic review and meta-analysis of randomized controlled trials. BMC Surgery, 17 (1), 2017.

13- DEMETRASHVILI Z., QERQADZE V., KAMKAMIDZE G., TOPCHISHVILI G., LAGVILAVA L., CHARTHOLANI T. and ARCHVADZE V.: Comparison of Lichtenstein and Laparoscopic Transabdominal Preperitoneal Repair of Recurrent Inguinal Hernias. International Surgery, 96 (3): 233-8, 2011.

14- O'REILLY E.A., BURKE J.P. and O'CONNELL P.R.: A meta-analysis of surgical morbidity and recurrence after laparoscopic and open repair of primary unilateral inguinal hernia. Annals of Surgery, 255 (5): 846-53, 2012.

15- WANG K.S.: Assessment and management of inguinal hernia in infants. Pediatrics, 130 (4): 768-73, 2013.

16- QUISPE M.R.F. and SALGADO JÚNIOR W.: Transabdominal preperitoneal (TAPP) versus open Lichtenstein hernia repair. Comparison of the systemic inflammatory response and the post-operative pain. Acta Cirurgica Brasileira, 34 (2), 2019.

17- O'CONNELL P.R. and WILLIAMS N.: Bailey \&Love's Short Practice of Surgery 26E. Crc Press; Chap. 5: PP. 29-33, 2013.

18- WENNERGREN J.E., PLYMALE M., DAVENPORT D., et al.: Quality-of-life scores in laparoscopic preperitoneal inguinal hernia repair. Surg. Endosc., 30 (8): 3467-73, 2016.

19- WIJERATHNE S., AGARWAL N., RAMZI A., et al.: Single-port versus conventional laparoscopic total extraperitoneal inguinal hernia repair: A prospective, randomized, controlled clinical trial. Surg. Endosc., 30 (4): 1356-63, 2016.

\title{
دراسة مقارنة ما بين إصلاح الفتق القريى الآولى من ثاحية واحلدة جراحياً عن طريق المنظار بطريقة (TAPP)
}

\author{
الخلفية: تم إجراء هذا البحث فى مستشفى الزهراء الجامعى ومستشفى كوبرى القبة العسكرى لدراسة مقارنة نتائج طريقتين جراحيتين \\ مختلفتين لتصليح الفتق القربى عن طريق القتح التقليدى وعن طريق الفئى النظار الجراحى. \\ الهدف من البحث: هو مقارنة نتائج تصليح الفتق القربى عن طريق الفتح الجراحى والتصليح عن طريق المنظار الجراحى.

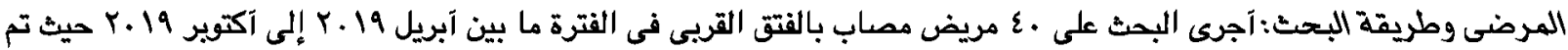

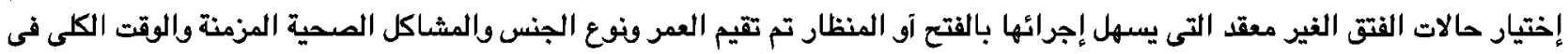 \\ العملية والمشاكل الصحية المترتبة على إجراء الجراحة والآلم ما بعد العملية فى كل من المجموعتين العين ومقارنتهم بالآبحاث المنشوره.

$$
\text { النتائج: تم إصلاح الفتق جراحى إلى • r مريض (مجموعة آ) وبالمنظار (TAPP) J • r مريض (مجموعة ب). }
$$

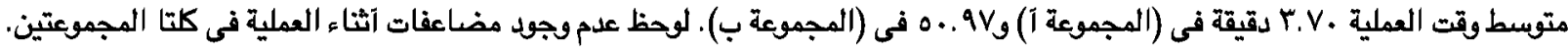

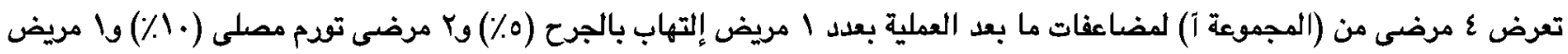

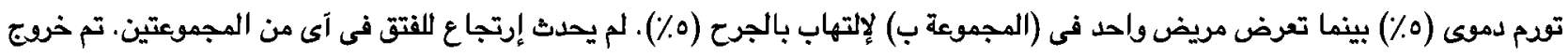

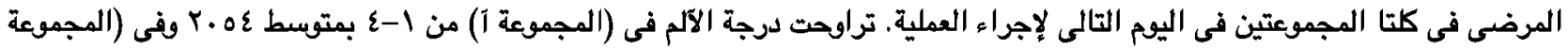

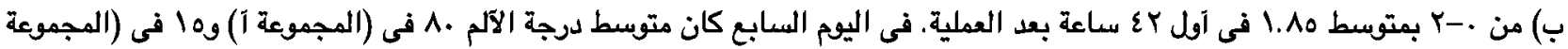

الإستتاج: نستطيع آن نلخص آن عملية تصليح الفتق بالنظظار لها نتائج جيدة إذا ما قورنت بطريقة الفتح ويجب آن توضع موضع الإعتبار 